\title{
Peran Notaris-PPAT dalam Pembuatan Akta Pembiayaan Kepemilikan Rumah Melalui Bank Syariah
}

\author{
Husain Asmara DM. \\ Magister Kenotariatan Fakultas Hukum Universitas Islam Indonesia \\ Jln. Cik Di Tiro No. 1, Yogyakarta, 55223 \\ husainasmara@gmail.com
}

\begin{abstract}
This research was conducted to analyze the role of the Notary and Land Titles Registrar (PPAT) in the drafting of the deed of financing a home ownership through a Sharia Bank and what obstacles were experienced in the financing method. This research uses a normative approach with a literature study supported by the results of the interview. The results show that the Notary has a different role when becoming a partner of Bank Muamalah Yogyakarta and Bank BTN Yogyakarta. In addition, the Notary also made a certificate of financing recognition, a Purchase Binding Agreement (PPJB), a Buy Back Guarentee Deed, and a Power of Attorney Imposing Mortgage Rights (SKMHT). While the role of PPAT is to make Deed of Sale and Purchase Deed of Mortgage Right (APHT). In making APHT, the PPAT cannot convert into a financing guarantee because its default provisions have been regulated in the Head of the Republic of Indonesia's National Land Agency Regulation No. 8 of 2012 concerning Land Registration, therefore the PPAT still writes it as a debt guarantee. As for several obstacles experienced, among others, the number of customers who do not comprehend the Islamic contract, the absence of one of the parties during the reading and signing of the deed, as well as the process involving BPN which is still too complex that the acceleration method at BPN is often used.
\end{abstract}

Keywords: Sharia bank; land titles registrar (PPAT); home ownership financing; notary role

\begin{abstract}
Abstrak
Penelitian ini dilakukan untuk mengetahui bagaimana peran Notaris-Pejabat Pembuat Akta Tanah (PPAT) dalam pembuatan akta pembiayaan kepemilikan rumah melalui Bank Syariah serta hambatan apa yang dialami dalam metode pembiayaan tersebut. Penelitian ini menggunakan pendekatan normatif dengan studi kepustakaan yang didukung oleh hasil wawancara. Hasilnya menunjukkan bahwa Notaris memiliki peran yang berbeda pada saat menjadi rekanan Bank Muamalah Yogyakarta dan Bank BTN Yogyakarta. Sebagai tambahan, Notaris juga membuat akta pengakuan pembiayaan, Perjanjian Pengikatan Jual Beli (PPJB), Akta Buy Back Guarentee, dan Surat Kuasa Membebankan Hak Tanggungan (SKMHT). Sedangkan peran PPAT yaitu membuatkan Akta Jual Beli dan Akta Pemberian Hak Tanggungan (APHT). Dalam pembuatan APHT, PPAT tidak bisa mengubah menjadi jaminan pembiayaan karena ketentuan bakunya sudah diatur dalam Peraturan Kepala Badan Pertanahan Nasional Republik Indonesia Nomor 8 Tahun 2012 tentang Pendaftaran Tanah, maka dari itu PPAT tetap menulisnya sebagai jaminan hutang. Adapun beberapa kendala yang dialami dalam antara lain banyaknya nasabah yang belum mengetahui akad syariah, dalam pembacaan dan penandatanganan akta salah satu pihak tidak hadir, juga proses yang melibatkan BPN masih terlalu lama sehingga sering menggunakan cara percepatan di BPN.
\end{abstract}

Kata-kata Kunci: Bank syariah; pejabat pembuat akta tanah (PPAT); pembiayaan kepemilikan rumah; peran notaris 


\section{Pendahuluan}

Perubahan Undang-Undang Nomor 30 Tahun 2004 tentang Jabatan Notaris melalui Undang-Undang Nomor 2 Tahun 2014 tentang Jabatan Notaris dinyatakan bahwa Notaris adalah pejabat umum yang berwenang untuk membuat Akta Autentik dan memiliki kewenangan lainya sebagaimana dimaksud dalam undangundang ini atau berdasarkan undang-undang lainnya. ${ }^{1}$ Peraturan Pemerintah Nomor 37 Tahun 1998 tentang Peraturan Jabatan Pejabat Pembuat Akta Tanah, Konsep PPAT dalam PP ini, tercantum dalam Pasal 1 angka 1, PPAT adalah pejabat umum yang diberi wewenang untuk membuat akta autentik mengenai perbuatan hukum tertentu mengenai hak atas tanah atau hak milik atas satuan rumah susun. ${ }^{2}$

Dalam Pasal 1867 KUHPerdata disebutkan ada istilah Akta Autentik, dan Pasal 1868 KUHPerdata memberikan batasan secara unsur yang dimaksud dengan Akta Autentik yaitu :3

a. Akta itu harus dibuat oleh (door) atau di hadapan (ten overstaan) seorang Pejabat Umum.

b. Akta itu harus dibuat dalam bentuk yang ditentukan oleh undang-undang.

c. Pegawai Umum (Pejabat Umum) oleh atau di hadapan siapa akta itu dibuat, harus mempunyai wewenang untuk membuat akta tersebut.

Rumah merupakan kebutuhan dasar manusia sebagai kebutuhan utama manusia maka rumah diminati banyak orang terutama para pengantin baru. Namun, harga rumah yang melambung tinggi menyebabkan jarang orang mampu membeli rumah secara tunai, sehingga membeli dengan angsuran atau menyewa adalah alternatif yang dipilih. Banyak cara yang dapat ditempuh oleh masyarakat dalam memenuhi kebutuhan pokok mereka dalam hal perumahan. Di sinilah Bank muncul menjembatani kepentingan pembeli dan penjual rumah dengan menawarkan fasilitas KPR (Kredit Pemilikan Rumah).

Bank Syariah merupakan Bank yang menawarkan fasilitas pembiayaan kepemilikan rumah yang diaplikasikan dengan akad murabahah, dan akad istishna' yang dianggap paling simpel dan efisien, hal ini membuat sebagian masyarakat hlm. 1 .

${ }^{1}$ M. Luthfan Hadi Darus, Hukum Notariat dan Tanggungjawab Jabatan Notaris, UII Press, Yogyakarta, 2017,

2 Salim HS, Teknik Pembuatan Akta Pejabat Pembuat Akta Tanah (PPAT), PT Raja Grafindo Persada, Jakarta, 2016, hlm. 87.

${ }^{3}$ Habib Adjie, Kebatalan Dan Pembatalan Akta Notaris, PT Refika Aditama, Bandung, 2011, hlm. 5. 
tertarik untuk menggunakan fasilitas pembiayaan tersebut yang sudah jelas terhindar dari riba. Salah satu elemen penting untuk dapat terlaksananya pembiayaan murabahah dan isthisna' oleh Bank BTN Syariah dan Bank Muamalah adalah akad yang dilakukan antara pihak Bank dengan nasabah. Dalam hal ini akad yang dilakukan berdasarkan Hukum Islam4 . Hal inilah yang membuat penulis memilih Bank Syariah sebagai rujukan untuk meneliti lebih lanjut terkait dengan pelaksanaan pemberian pembiayaan kepemilikan rumah. Penulis memilih Bank BTN syariah dan Bank Muamalah untuk dijadikan bahan data penelitian karena Bank BTN mewakili Bank Negara sedangkan Bank Muamalah mewakili Bank swasta yang keduanya bergerak dalam bidang perbankan syariah, dari kedua Bank tersebut apakah nantinya mempunyai kesamaan atau perbedaan dalam mengaplikasikan perjanjian baik di bawah tangan ataupun perjanjian secara autentik.

Dalam pemberian fasilitas pembiayaan kepemilikan rumah, tidak lepas dari peranan Notaris dan PPAT, karena melalui Notaris dan PPAT pihak Bank dan nasabah menuangkan perjanjian yang dibuat, agar bisa dijadikan sebagai alat bukti yang autentik atau bukti yang sempurna, sehingga para pihak yang membuat perjanjian akan terlindungi dengan adanya kepastian hukum, namun Notaris dalam menuangkan perjanjian yang dibuat oleh para penghadap atau para pihak Notaris wajib "bertindak secara amanah, jujur, mandiri, tidak berpihak, dan menjaga kepentingan pihak yang terkait dalam perbuatan hukum."5 Dari kutipan Pasal 16 ayat (1) UUJN tersebut dapat disimpulkan bahwasanya Notaris haruslah bersikap adil dan tidak memihak salah satu pihak, melainkan Notaris haruslah netral dalam menuangkan perjanjian yang dibuat oleh para pihak. Begitu pula dengan PPAT di dalam Kode etik PPAT disebutkan dalam Pasal 3 huruf e PPAT wajib "bekerja dengan penuh rasa tanggung jawab, mandiri, jujur dan tidak berpihak"6 dari isi Pasal tersebut PPAT tidak jauh beda dengan Notaris karena

${ }^{4}$ Wawancara dengan staf administrasi PT Riscon Realty Cabang Yogyakarta.

${ }^{5}$ Undang-Undang Nomor 2 Tahun 2014 tentang Jabatan Notaris, Pasal 16, ayat (1).

${ }^{6}$ Kode Etik Pejabat Pembuat Akta Tanah, Pengubahan ke-II hasil penyesuaian dengan perubahan Anggaran Dasar Keputusan Kongres IV IPPAT di Surabaya tanggal 31 Agustus- 1 September 2007, Pasal 3 Huruf e. 
PPAT juga harus bersikap jujur dan tidak berpihak dalam menjalankan tugasnya, agar tidak ada pihak yang merasa dirugikan.

Perjanjian atau akad pembiayaan merupakan perjanjian pokok yang nantinya akan diikuti dengan perjanjian accessoir atau perjanjian pengikat jaminan yang berupa Akta pemberian Hak Tanggungan (APHT) merupakan pengikatan jaminan hutang yang dibuat di hadapan PPAT Pejabat Pembuat Akta Tanah (PPAT). APHT adalah, "Akta Pejabat Pembuat Akta Tanah yang berisi pemberian Hak Tanggungan kepada kreditor tertentu sebagai jaminan untuk pelunasan piutangnya". ${ }^{7}$

Dalam pembuatan perjanjian accessoir harus mengikuti perjanjian pokoknya, apabila perjanjian pokok menggunakan pembiayaan, maka perjanjian pengikatan jaminan atau accessoir tersebut dibuat berdasarkan penjaminan pembiayaan, di sini penulis akan mengkaji apakah perjanjian accessoir tersebut sudah sesuai dengan perjanjian pokoknya atau belum, atau justru perjanjian accessoir-nya tidak sesuai dengan perjanjian pokoknya, di sinilah letak peran Notaris dan PPAT yang sangat penting apakah Notaris-PPAT tersebut sudah melaksanakan tugas jabatannya dengan benar atau justru sebaliknya.

Dengan demikian, berdasarkan uraian di atas, penulis tertarik untuk mengkaji lebih dalam mengenai peran Notaris-PPAT dalam pembuatan akta pembiayaan kepemilikan rumah melalui Bank Syariah.

\section{Rumusan Masalah}

Berdasarkan pendahuluan di atas maka rumusan masalah pada penelitian ini adalah: pertama, bagaimana peran Notaris-PPAT dalam pembuatan akta pembiayaan kepemilikan rumah melalui Bank Syariah? Kedua, hambatan apa yang dihadapi dalam pembuatan akta pembiayaan kepemilikan rumah melalui Bank Syariah?

\section{Tujuan Penelitian}

Tujuan penelitian ini bertujuan untuk mengetahui: pertama, peran NotarisPPAT dalam pembuatan akta pembiayaan kepemilikan rumah melalui Bank

${ }^{7}$ Undang-undang Nomor 4 Tahun 1996 tentang Hak Tanggungan atas Tanah Beserta benda-benda yang berkaitan dengan Tanah, Pasal 1 ayat (5). 
Syariah; dan kedua, hambatan apa yang dihadapi dalam pembuatan akta pembiayaan kepemilikan rumah melalui Bank Syariah.

\section{Metode Penelitian}

Agar penelitian berjalan dengan baik dan memperoleh hasil yang dapat dipertanggungjawabkan, maka penelitian ini memerlukan suatu metode tertentu. Metode yang digunakan dalam penelitian ini adalah sebagai berikut :

\section{Obyek Penelitian}

Obyek penelitian ini adalah peran Notaris-PPAT dalam pembuatan akta pembiayaan kepemilikan rumah melalui Bank Syariah. Penelitian ini akan menganalisis sejauh mana peran Notaris-PPAT dalam pembuatan akta pembiayaan kepemilikan rumah melalui Bank Syariah.

\section{Narasumber}

Narasumber pada penelitian ini adalah: (1) Notaris yang menjadi rekanan Bank BTN Syariah dan Muamalah; (2) PPAT yang menjadi rekanan Bank BTN Syariah dan Muamalah; (3) Bank BTN Syariah Yogyakarta; (4) Bank Muamalah Yogyakarta

\section{Data Penelitian}

Dalam penelitian ini data yang diutamakan dari data sekunder, yaitu merupakan data yang diperoleh melalui studi perpustakaan baik itu dari aspek teori, perbandingan struktur/komposisi, konsistensi, Peraturan perundangundangan, buku, jurnal atau literatur yang berkaitan dengan penelitian ini, kemudian didukung dengan perolehan data primer dengan narasumber.

\section{Teknik Pengumpulan Data}

\section{Studi Pustaka}

Dilakukan dengan cara studi kepustakaan, penulis mempelajari berbagai literatur yang berkaitan dengan objek kajian penelitian ini. Dalam penelitian ini, penulis melakukan inventarisasi terhadap bahan-bahan hukum yang diperlukan, seperti bahan-bahan primer, bahan-bahan sekunder, bahan-bahan tersier yang terkait tentang peran Notaris-PPAT dalam pembuatan akta pembiayaan kepemilikan rumah melalui Bank Syariah. 


\section{Wawancara}

Proses wawancara dilakukan dengan cara bertanya jawab dengan narasumber yang terkait dalam masalah ini. Metode wawancara yang digunakan adalah wawancara terstruktur, yakni di samping menyusun pertanyaan, juga akan mengembangkan pertanyaan lain yang berhubungan dengan masalah penelitian yang dilakukan.

\section{Pendekatan Penelitian}

Pendekatan yang dipergunakan dalam penelitian ini untuk melihat permasalahan di atas dengan pendekatan undang-undang (statute approach), penulis mengkaji baik berdasarkan hukum tertulis (Undang-Undang Jabatan Notaris dengan Peraturan Pemerintah tentang Pejabat Pembuat Akta Tanah serta hukum tertulis lain yang berkaitan dengan permasalahan ini) maupun hukum tidak tertulis serta dengan cara melihat langsung peran Notaris-PPAT dalam pembuatan akta pembiayaan kepemilikan rumah melalui Bank Syariah.

\section{Analisis Data}

Dalam penulisan tesis ini menggunakan teknik analisis data deskriptif kualitatif. Analisis deskriptif merupakan kegiatan pengkajian hasil olah data yang hanya sampai pada taraf deskripsi, yaitu menyajikan dan menafsirkan fakta secara sistematik sehingga dapat lebih mudah dipahami dan disimpulkan', sedangkan data kualitatif merupakan data yang tidak berbentuk angka, tetapi lebih banyak berupa narasi, cerita, dokumen tertulis dan tidak tertulis, (gambar dan foto) atau bentuk-bentuk non-angka lain. ${ }^{9}$

\section{Hasil Penelitian dan Pembahasan}

Peran Notaris-PPAT dalam Pembuatan Akta yang Terkait dengan Pembiayaan Kepemilikan Rumah

Peran Notaris dalam Pembuatan Akta yang Terkait dengan Pembiayaan Kepemilikan Rumah Melalui Bank Syariah

Notaris berperan sangat penting dalam pembuatan akta yang terkait pembiayaan kepemilikan rumah, tidak hanya membuat akta, peran Notaris juga melakukan legalisasi terhadap perjanjian yang dibuat oleh pihak bank dan

\footnotetext{
${ }^{8}$ M. Syamsudin, Operasionalisasi Penelitian Hukum, PT Rajarafindo Persada, Jakarta, 2007, hlm. 127.

${ }^{9}$ Ibid., hlm. 133
} 
nasabah, Kewenangan Notaris, menurut Pasal 15 UUJN adalah membuat Akta Autentik mengenai perbuatan, perjanjian dan ketetapan yang diharuskan oleh peraturan perundang-undangan dan/atau yang dikehendaki oleh yang berkepentingan untuk dinyatakan dalam Akta Autentik, menjamin kepastian tanggal pembuatan Akta, menyimpan Akta, memberikan grosse, salinan dan kutipan Akta, semuanya itu sepanjang pembuatan Akta-Akta itu tidak juga ditugaskan atau dikecualikan kepada pejabat lain atau orang lain yang ditetapkan oleh undang-undang. ${ }^{10}$

Dari penjelasan tersebut kewenangan Notaris sangatlah luas terkait dalam pembuatan Akta Autentik selama tidak dikecualikan kepada pejabat lain yang ditetapkan oleh undang-undang. Dalam menjalankan tugasnya di Bank BTN Syariah Yogyakarta Notaris melegalisasi akad murabahah serta akad wakalah yang dibuat oleh Bank dengan nasabah, dan melegalisasi akad istishna' yang dibuat oleh Bank dengan developer, dan Bank dengan nasabah yang diikuti dengan akad wakalah, berbeda dengan Bank Mualamalah untuk akad pembiayaan kepemilikan rumah ditambah dengan akad Musyarakah Muatanaqisah yang tidak diikuti dengan akad wakalah, khusus di Bank Muamalah apabila nilai transaksinya lebih dari lima ratus juta rupiah maka dibuat dalam bentuk Akta Autentik. Selain melegalisasi Notaris juga membuatkan akta Perjanjian Pengikatan Jual Beli (PPJB) antara nasabah dengan developer, Akta buy back guarentee antara Developer dengan Bank, Akta Pengakuan Pembiayaan antar Bank dengan nasabah, dan Surat Kuasa Membebankan Hak Tanggungan (SKMHT) ${ }^{11}$ antara nasabah dengan Bank, namun dalam pelaksanaan SKMHT dapat dibuat pula oleh PPAT sebagaimana yang diatur dalam Peraturan Pemerintah Nomor 37 Tahun 1998 tentang Pejabat Pembuat Akta Tanah.

Dalam menjalankan tugasnya Notaris harus berpedoman dengan UUJN serta Kode Otik Notaris, apabila tidak berpedoman atau melanggar peraturan tersebut

\footnotetext{
${ }^{10}$ Abdul Ghofur Anshori, Lembaga Kenotariatan Indonesia Prespektif Hukum Dan Etika, UII Pres, Yogyakarta, 2009, hlm. 15.

11 Wawancara dengan Notaris-PPAT Bapak Ir. Edwin Rusdi S.H., M. Kn. di Bantul, pada tanggal 3 September 2018 .
} 
tentu dampaknya bisa fatal, karena akta tersebut bisa turun derajatnya menjadi akta di bawah tangan serat akta tersebut bisa dibatalkan dan batal demi hukum. Akta Notaris yang mempunyai kekuatan pembuktian di bawah tangan dicantumkan secara tegas dalam pasal-pasal tertentu dalam UUJN yang menyebutkan jika dilanggar oleh Notaris maka akta tersebut mempunyai kekuatan pembuktian di bawah tangan, seperti dalam Pasal 16 ayat (1) huruf i yaitu tidak membacakan akta di hadapan penghadap dengan dihadiri oleh paling sedikit 2 orang saksi dan ditandatangani pada saat itu juga oleh penghadap, saksi dan Notaris", Pasal 16 ayat (7) dan ayat (8) yaitu, jika Notaris pada akhir akta tidak mencantumkan kalimat bahwa para penghadap menghendaki agar akta tidak dibacakan karena penghadap membaca sendiri, mengetahui, dan memahami isi akta.

Dalam pembuatan Akta PPJB dan AJB, Notaris pernah tidak memenuhi Pasal 16 ayat (1) huruf i UUJN karena ada pihak yang tidak bisa hadir saat melakukan pembacaan sekaligus penandatanganan akta, dikarenakan sedang berada di luar kota, yaitu direktur dari PT Riscon Realty, tentu hal ini menjadi masalah bagi Notaris, karena pembacaan akta sekaligus penandatanganan akta tidak dapat dilakukan, sehingga memaksa Notaris tersebut mempersilahkan nasabah untuk menandatangani terlebih dahulu baru dari pihak developer menyusul ${ }^{12}$, hal ini tentu melanggar peraturan yang dimuat dalam UUJN yang dapat mengakibatkan akta tersebut menjadi akta yang mempunyai kekuatan pembuktian di bawah tangan. Akta tersebut akan tetap menjadi akta yang autentik apabila para pihak atau yang bersangkutan tidak mengajukan gugatan perdata ke pengadilan. Dalam hal ini, sebaiknya Notaris tidak melakukan hal demikian, seharusnya Notaris membuatkan Surat Kuasa untuk terhadap manajer yang berada di Yogyakarta untuk melakukan jual beli atau mewakili direktur yang bertempat di Jakarta Pusat.

Apabila Notaris melanggar ketentuan Pasal 16 ayat (1) huruf i secara otomatis Notaris juga melanggar ketentuan Pasal 16 ayat (1) huruf a yang mewajibkan Notaris tersebut harus "bertindak amanah, jujur, sesama, mandiri, tidak berpihak dan menjaga kepentingan pihak yang terkait dalam perbuatan hukum". ${ }^{13}$ Tentu Notaris dalam menjalankan tugasnya harus bertindak amanah, jujur dan tidak

\footnotetext{
12 Wawancara manager PT Riscon Realty Cabang Yogyakarta, pada tanggal 12 September 2018.

${ }^{13}$ Uundang-Undang No. 2 Tahun 2004 tentang Jabatan Notaris Pasal 16 Ayat (1) Huruf a.
} 
memihak, apabila Notaris melanggar ketentuan tersebut tentu Notaris dapat dikenai sanksi sebagaimana diatur dalam UUJN Pasal 16 ayat (11) "Notaris yang melanggar ketentuan sebagaimana dimaksud pada ayat 1 huruf a sampai dengan huruf i dapat dikenakan sanksi berupa; peringatan tertulis, pemberhentian sementara, pemberhentian dengan hormat, atau pemberhentian dengan tidak hormat. Oleh sebab itu Notaris dalam menjalankan tugasnya harus berpedoman dengan undang-undang Jabatan Notaris dan Kode etik Notaris.

\section{Peran PPAT dalam Pembuatan Akta yang Terkait dengan Pembiayaan Kepemilikan Rumah Melalui Bank Syariah.}

Peran PPAT dalam pembuatan akta yang terkait dengan pembiayaan kepemilikan rumah hanya membuatkan akta SKMHT (surat kuasa membebankan hak tanggungan) dan AJB (akta jual beli) maka dari itu peran dari PPAT sangatlah sedikit dibandingkan dengan peran Notaris, karena Tugas pokok PPAT telah ditentukan dalam Pasal 2 Peraturan Pemerintah Nomor 37 Tahun 1998 tentang Peraturan Jabatan Pejabat Pembuat Akta Tanah. Di luar kedelapan tugas pokok PPAT tersebut bukanlah kewenangan PPAT melainkan kewenangan Notaris. Dalam menjalankan tugas PPAT harus berpedoman dengan Pemerintah Nomor 37 Tahun 1998 tentang Peraturan Jabatan Pejabat Pembuat Akta Tanah serta Kode etik yang mengatur mengenai Pejabat Pembuat Akta Tanah. Dalam praktik pembiayaan kepemilikan rumah melalui Bank Syariah PPAT membuatkan Akta Jual Beli (AJB), SKMHT dan membuatkan Akta Pembebanan Hak Tanggungan (APHT),

APHT adalah "Akta Pejabat Pembuat Akta Tanah yang berisi pemberian Hak Tanggungan kepada kreditor tertentu sebagai jaminan untuk pelunasan piutangnya".14 Bentuk APHT diatur dalam Peraturan Kepala Badan Pertanahan Nasional Republik Indonesia Nomor 08 Tahun 2012 tentang Perubahan Atas Peraturan Menteri Agraria/Kepala Badan pertanahan Nasional Nomor 03 Tahun 1997 tentang Ketentuan Pelaksanaan Peraturan Pemerintah Nomor 24 Tahun 1997 tentang Pendaftaran Tanah. APHT Harus dibuat di hadapan Pejabat Pembuat Akta

${ }^{14}$ Undang-Undang Nomor 4 Tahun 1996 tentang Hak Tanggungan atas Tanah Beserta Benda-Benda yang Berkaitan dengan Tanah, Pasal 1 ayat (5). 
Tanah (PPAT), hal ini sesuai dengan Pasal 2 ayat (2) huruf g Peraturan Pemerintah Nomor 24 Tahun 2016 atas perubahan Peraturan Pemerintah Nomor 37 Tahun 1998 tentang Pejabat Pembuat Akta Tanah, yang berkaitan tentang tugas pokok dan kewenangan PPAT yaitu membuat Akta Pemberian Hak Tanggungan (APHT).

Pembiayaan kepemilikan rumah melalui Bank Syariah merupakan sebuah fasilitas yang diberikan oleh Bank terhadap nasabah, sehingga pembiayaan tersebut bukanlah hutang, melainkan sebuah fasilitas pembiayaan, sehingga Bank BTN Syariah dan Bank Muamalah Yogyakarta tidak mau menyebutnya sebagai hutang. Bank BTN Syariah Yogyakarta menambahkan perjanjian pengakuan pembiayaan yang dituangkan dalam Akta Autentik yang dibuat oleh Notaris dalam pemberian pembiayaan kepemilikan rumah yang dijadikan dasar untuk dibuatnya Akta Pemberian Hak Tanggungan.

Sudah jelas disebutkan bahwasanya bentuk dari Akta Pemberian Hak Tanggungan sudah diatur dalam Peraturan Kepala Badan Pertanahan Nasional Republik Indonesia Nomor 08 Tahun 2012 tentang Perubahan Atas Peraturan Menteri Agraria/Kepala Badan pertanahan Nasional Nomor 03 Tahun 1997 tentang Ketentuan Pelaksanaan Peraturan Pemerintah Nomor 24 Tahun 1997 tentang Pendaftaran Tanah. Sehingga bentuknya sudah baku karena sudah ditetapkan dalam peraturan, oleh sebab itu PPAT tidak bisa berbuat banyak dalam pembuatan APHT karena apabila dalam isi akta tersebut diubah menjadi jaminan pembiayaan maka Badan Pertanahan Nasional tingkat Kabupaten atau Kota tidak mau menerima karena tidak sesuai dengan peraturan Badan Pertanahan Nasional. Oleh sebab itu, peran PPAT sebagai pembuat APHT tentu tidak bisa disalahkan karena hal ini bukanlah kesalahan dari PPAT, melainkan peraturan yang sudah mengatur demikian. Sebenarnya Notaris dapat membuatkan Akta Pengakuan Hutang sebagai perjanjian pokok, namun hal ini bertentangan dengan kehendak Bank yang tidak mau menyamakan pembiayaan sebagai hutang.

\section{Hambatan yang Dihadapi Notaris-PPAT dalam Pembuatan Akta Pembiayaan Kepemilikan Rumah Melalui Bank Syariah}

Dalam pelaksanaan pembiayaan kepemilikan rumah tentu ada kendala yang dialami oleh beberapa pihak yang terkait, oleh sebab itu kendala-kendala ini diharapkan untuk ke depannya dapat teratasi oleh para pihak yang terkait baik 
dari pihak Bank, Developer, Notaris-PPAT, serta nasabah. Adapun kendala yang dialami dalam pelaksanaan pembiayaan kepemilikan rumah ialah sebagai berikut.

Dari pihak Bank kendalanya adalah masih banyak nasabah yang belum mengenal dan memahami dengan baik prinsip-prinsip syariah, banyak nasabah yang belum dapat membedakan apa itu akad jual-beli yaitu murabahah, istisna, salam dengan akad bagi hasil yaitu mudharabah, musyarakah, ataupun dengan akad sewa menyewa yaitu ijaroh. Padahal secara prinsip dari ketiga jenis akad penyaluran dana/pembiayaan yang dapat diterapkan pada bank syariah tersebut terdapat perbedaan secara prinsip. Oleh sebab itu perlu diadakannya sosialisasi kepada masyarakat agar masyarakat paham dengan apa yang dimaksud dengan akad syariah, serta akad apa saja yang tepat dan dapat diterapkan dalam pembiayaan. ${ }^{15}$

Kendala yang dialami oleh Notaris-PPAT yaitu terkait dalam pembuatan akta, terutama pada saat pembacaan serta penandatanganan akta, karena jika salah satu pihak tidak hadir maka pembacaan serta penandatanganan akta tersebut diundur, namun dalam kenyataannya Notaris tetap melaksanakan penandatanganan akta tersebut. ${ }^{16} \mathrm{Hal}$ ini tentu menyalahi peraturan yang ada, namun disisi lain para pihak sudah mempercayakan kepada Notaris karena sudah menjadi rekanan untuk mengurus pembuatan akta tersebut, dan tidak semua pihak mengetahui akibat dari tidak terpenuhinya hal tersebut bisa menjadi menjadi perjanjian di bawah tangan yang kekuatan pembuktiannya menjadi di bawah tangan. Dalam hal ini penulis menyarankan bahwasanya apabila salah satu pihak tidak bisa hadir dalam pembuatan akta sebaiknya dalam pelaksanaannya dapat diwakilkan melalui surat kuasa yang sekurang-kurangnya dilegalisasi oleh Notaris, sehingga akta tersebut kekuatan pembuktiannya tidak turun menjadi perjanjian di bawah tangan.

Kendala yang dialami oleh Notaris-PPAT selain hal tersebut ialah mengenai pembuatan APHT yang ketentuan bakunya sudah diatur dalam Peraturan Kepala

\footnotetext{
15 Wawancara dengan staf legal Bank BTN Syariah Yogyakarta.

16 Wawancara dengan Notaris sekaligus PPAT bapak Ir. Edwin Rusdi S.H., M. Kn. di Bantul yang menangani Pembiayaan Kepemilikan Rumah melalui Bank Syariah.
} 
Badan Pertanahan Nasional Republik Indonesia Nomor 08 Tahun 2012 tentang Perubahan Atas Peraturan Menteri Agraria/Kepala Badan pertanahan Nasional Nomor 03 Tahun 1997 tentang Ketentuan Pelaksanaan Peraturan Pemerintah Nomor 24 Tahun 1997 tentang Pendaftaran Tanah, yang mana dalam ketentuan tersebut harus ditulis sebagai jaminan hutang, sedangkan pembiayaan kepemilikan rumah melalui Bank syariah bukanlah sebagai hutang, namun sebagai pembiayaan. Apabila di dalam akta tersebut ditulis sebagai jaminan pembiayaan maka APHT tersebut dapat di tolak oleh Badan Pertanahan Nasional tingkat Kabupaten atau Kota karena tidak sesuai dengan peraturan, Oleh sebab itu sebagai Notaris dan PPAT yang terlibat dalam pembuatan akta pembiayaan kepemilikan rumah tersebut tidak bisa berbuat banyak kecuali menaati peraturan Kepala Badan Pertanahan Nasional tersebut. Dalam hal ini penulis berpendapat bahwasanya Kepala Badan Pertanahan Nasional bisa mengeluarkan kebijakan melalui peraturan yang baru, sehingga apabila Bank Syariah ingin memasang Hak Tanggungan dapat ditulis sebagai jaminan pembiayaan.

Kendala yang dialami oleh Developer ialah mengenai pemecahan sertifikat induk di Badan Pertanahan Nasional tingkat Kota atau Kabupaten yang memakan proses yang lama, untuk menyikapi hal tersebut para pihak menempuh jalan dengan cara melalui proses percepatan, untuk proses di BPN ini tidak hanya untuk pemecahan sertifikat melainkan segala proses yang melibatkan BPN. ${ }^{17} \mathrm{Hal}$ ini terkesan menjadi budaya atau kebiasaan bagi BPN untuk melakukan atau menempuh jalan melalui proses percepatan. Dalam hal ini penulis berpendapat bahwasanya BPN seharusnya tidak melakukan hal tersebut, karena BPN bertugas melayani masyarakat dalam hal yang terkait dengan pertanahan, Penulis berharap ke depannya Pemerintah melakukan pengawasan terhadap BPN baik tingkat Kota atau Kabupaten, agar ke depannya tidak ada lagi proses percepatan yang mengakibatkan penambahan biaya dan penulis berharap proses yang melibatkan BPN dapat berjalan secara jujur, adil dan amanah.

17 Wawancara dengan Manager PT Riscon Realty Cabang Yogyakarta. 


\section{Penutup}

Peran Notaris dalam pembuatan akta yang terkait dengan pembiayaan kepemilikan rumah yaitu melegalisasi akad atau perjanjian serta membuat Akta Autentik, dalam praktik di Bank BTN Syariah Yogyakarta Notaris melegalisasi akad murabahah yang diikuti dengan akad wakalah, dan akad istishna' yang diikuti dengan akad wakalah, dan Notaris membuatkan Akta pengakuan pembiayaan sebagai penegasan dalam pembiayaan kepemilikan rumah. Praktik Notaris di Bank Muamalah Yogyakarta melegalisasi akad syariah berupa akad murabahah yang diikuti dengan akad wakalah, akad istishna' yang diikuti dengan akad wakalah, dan akad musyarakah mutanaqisah. Apabila nilai pembiayaan mencapai Rp. 500.000.00,00 maka dibuat secara autentik. Selain melegalisasi Notaris juga membuat Akta PPJB antara nasabah atau konsumen dengan developer, akta buy back guarentee sebagai bentuk jaminan developer terhadap Bank apabila nasabah mengalami macet dalam pembayaran, dan membuat SKMHT dari nasabah terhadap Bank. Dalam menjalankan tugasnya Notaris harus melaksanakan kewajiban Notaris yang termuat dalam UUJN ataupun Kode Etik Notaris. Apabila Notaris melanggar Pasal 16 ayat (1) huruf i UUJN yaitu membacakan isi akta yang diikuti penandatanganan akta, maka akibat yang timbul ialah akta tersebut kekuatan pembuktiannya turun menjadi akta di bawah tangan dan apabila Notaris melanggar pasal tersebut secara otomatis Notaris juga melanggar Pasal 16 ayat (1) huruf a yang mewajibkan harus bertindak amanah, jujur, dan tidak berpihak.

Peran PPAT yaitu membuatkan Akta Jual Beli (AJB) antar nasabah atau konsumen dengan developer, dan membuat APHT. Namun dalam pemasangan Hak Tanggungan dalam APHT tersebut ditulis sebagai jaminan hutang bukan sebagai jaminan pembiayaan sebagaimana yang tertuang dalam perjanjian pokoknya dalam akad pembiayaan kepemilikan rumah, tentu hal ini bukanlah kesalahan Notaris atau PPAT selaku pejabat umum melainkan dalam pembuatan APHT ketentuannya sudah diatur dalam Peraturan Kepala Badan Pertanahan Nasional Republik Indonesia, apabila PPAT dalam membuat APHT ditulis sebagai jaminan pembiayaan maka akan ditolak oleh Badan Pertanahan Nasional (BPN) dengan alasan tidak sesuai dengan peraturan yang telah ditetapkan oleh BPN. 
Padahal dalam teori disebutkan bahwasanya perjanjian accessoir harus mengikuti perjanjian pokoknya, dalam hal ini Notaris-PPAT harus menaati peraturan yang sudah ditetapkan oleh BPN guna diterimanya pemasangan Hak Tanggungan tersebut.

Hambatan yang dialami dalam pelaksanaan pembiayaan kepemilikan rumah melalui Bank Syariah ialah :

a) Dari pihak Bank kendalanya adalah masih banyak nasabah yang belum mengenal dan memahami dengan baik prinsip-prinsip syariah, sehingga pihak bank syariah melalui pegawainya yang terkait dalam pembiayaan kepemilikan rumah serta pemasaran yang menangani pembiayaan kepemilikan rumah harus dapat menjelaskan dengan baik kepada nasabahnya. Nasabah belum dapat memahami apa yang menjadi produk-produk dari bank yang menjalankan kegiatan usaha berdasarkan prinsip syariah, sehingga nasabah akan kesulitan untuk dapat mengetahui produk mana yang akan sesuai dengan kebutuhannya

b) Kendala yang dialami oleh Notaris-PPAT yaitu terkait dalam pembuatan akta, terutama pada saat pembacaan serta penandatanganan akta, karena jika salah satu pihak tidak hadir dan penandatanganan dilakukan tidak di hadapan Notaris maka kekuatan pembuktiannya turun menjadi Akta di bawah tangan.

c) Kendala yang dialami oleh Notaris-PPAT selain hal tersebut ialah mengenai pembuatan APHT yang ketentuan bakunya sudah diatur dalam Peraturan Kepala Badan Pertanahan Nasional Republik Indonesia, yang mengharuskan sebagai jaminan hutang, sedangkan pembiayaan bukanlah sebagai hutang, hal ini membuat Notaris-PPAT harus mematuhi peraturan BPN apabila tidak pemasangan Hak Tanggungan tersebut ditolak oleh BPN.

d) Pemecahan sertifikat induk di BPN tingkat Kota atau Kabupaten yang memakan proses yang lama, untuk menyikapi hal tersebut para pihak menempuh jalan dengan cara melalui proses percepatan, untuk proses di BPN ini tidak hanya untuk pemecahan sertifikat melainkan segala proses yang melibatkan BPN. Hal ini terkesan menjadi budaya atau kebiasaan bagi BPN untuk melakukan atau menempuh jalan melalui proses percepatan.

Maka dari itu, notaris harus memperdalam ilmu terkait dengan Perbankan Syariah serta perkembangannya Bank Syariah agar dalam pembuatan akta sesuai 
dengan ketentuan syariah dan tidak melanggar peraturan UUJN ataupun Kode Etik Notaris. Notaris-PPAT dalam menjalankan jabatannya harus menaati peraturan yang ada, agar tidak merugikan atau menimbulkan kerugian bagi para pihak yang bersangkutan, dan Notaris sebaiknya menerangkan terlebih dahulu akibat-akibat hukum yang ditimbulkan atas akta yang dibuat sebagai perjanjian, agar para pihak yang awam terhadap hukum akan merasa terlindungi.

BPN sebaiknya mengeluarkan kebijakan terhadap pembuatan APHT tidak hanya sebagai jaminan hutang saja, melainkan dapat dipasang sebagai jaminan pembiayaan, karena selama ini Bank Syariah membuat akad pembiayaan namun dipasang Hak Tanggungan sebagai jaminan hutang. Dalam pelaksaan pembiayaan kepemilikan rumah di Bank Syariah sebaiknya tidak hanya menerapkan sebagian akad saja, melainkan menawarkan semua akad yang dapat diterapkan dalam pembiayaan kepemilikan rumah, agar nasabah bisa memilih akad yang diinginkan dan tidak terkesan seperti kontrak baku yang dilegalisasi oleh notaris atau dibuat sebagai Akta Autentik.

\section{Daftar Pustaka}

\section{Buku}

Adjie, Habib, Kebatalan Dan Pembatalan Akta Notaris, PT Refika Aditama, Bandung, 2011.

Anshori, Abdul Ghofur, Lembaga Kenotariatan Indonesia Prespektif Hukum Dan Etika, UII Press, Yogyakarta, 2009.

Darus, M. Luthfan Hadi, Hukum Notariat dan Tanggungjawab Jabatan Notaris, UII Press, Yogyakarta, 2017.

H.S., Salim, Teknik Pembuatan Akta Pejabat Pembuat Akta Tanah (PPAT), PT Raja Grafindo Persada, Jakarta, 2016.

Syamsudin, M., Operasionalisasi Penelitian Hukum, PT Rajarafindo Persada, Jakarta, 2007.

\section{Undang-Undang}

Undang-Undang Nomor 4 Tahun 1996 tentang Hak Tanggungan atas Tanah Beserta Benda-Benda yang Berkaitan dengan Tanah.

Undang-Undang Nomor 30 Tahun 2004 tentang Jabatan Notaris.

Undang-Undang Nomor 2 Tahun 2014 tentang Jabatan Notaris. 


\section{Lain-Lain}

Kode Etik Pejabat Pembuat Akta Tanah, Pengubahan ke-II hasil penyesuaian dengan perubahan Anggaran Dasar Keputusan Kongres IV IPPAT di Surabaya tanggal 31 Agustus- 1 September 2007. 